\title{
Pozycja prawna skarbnika w mieście na prawach powiatu - na przykładzie Wrocławia
}

\# miasto na prawach powiatu \# kontrasygnata \# skarbnik \# Wrocław city under the law of the county \# countersignature \# treasurer \# Wrocław

W artykule zostanie przeprowadzona analiza pozycji skarbnika miasta na prawach powiatu na przykładzie Wrocławia. Uwzględnione w niej będą w szczególności jego kompetencje wyartykułowane w aktach prawa powszechnie i wewnętrznie obowiązującego, a także ograniczenia związane z powołaniem na stanowisko skarbnika. Dodatkowo, zakres artykułu obejmie procedurę powoływania i odwoływania skarbnika ze stanowiska. Zostanie także podniesiona kwestia kontrasygnaty jako wyrazu kontroli skarbnika nad finansami jednostki samorządu terytorialnego. Na zakończenie uwzględniona będzie odpowiedzialność, którą może ponieść skarbnik w ramach pełnionych zadań.

This article's purpose is to analysis the position of city's with powiat right treasurer by the example of the city of Wrocław. Particularly treasurers competencies and its legal act basis - both internal and external - and restrictions concerning appointment of such treasurer. A procedure of revokement form this position was shown as well. Also, raises a question about a countersign as a mean of control over finances of local government unit. Moreover, in the final segment of this article the responsibility of the treasurer within its duties are mentioned.

Miasto. Pamięć i Przyszłość 3/2 (2018) ISSN 2543-621X

\section{OPEN ACCESS}

Citation: Kossak D., Pozycja prawna skarbnika w mieście na prawach powiatu - na przykładzie Wrocławia, „Miasto. Pamięć i Przyszłość", $3 / 2$ (2018).

https://doi.org/10.26774/mpp.82

Editor: Jerzy Korczak

Received: October, 2018

Accepted: December, 2018

Published: December, 2018

Copyright: ๑ Ośrodek „Pamięć i Przyszłość" This is an open access article distributed under the terms of the Creative Commons Attribution-ShareAlike Licence, which permits unrestricted use, distribution, and reproduction in any medium, provided the original author and source are credited, with indications if any changes are made. All derivative works must be licensed under the same licence.

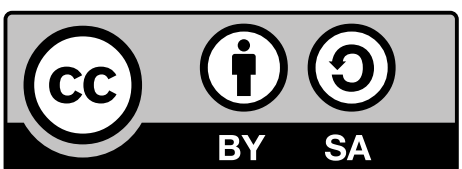


Dominik Kossak - student IV roku studiów prawniczych na Wydziale Prawa Administracji i Ekonomii Uniwersytetu Wrocławskiego, absolwent studiów I stopnia na kierunku ekonomia na tym samym wydziale, członek zarzadu Koła Naukowego Prawa Konstytucyjnego. 


\section{Uwagi wprowadzające}

Właściwe zarządzanie finansami miasta na prawach powiatu jest niezwykle istotne dla odpowiedniego funkcjonowania tej jednostki samorządu terytorialnego (JST). Dlatego też zostało ono powierzone skarbnikowi miasta, od którego wymaga się odpowiedniej znajomości nie tylko spraw z zakresu finansów publicznych, ale także kwestii podatkowych, z zakresu zamówień publicznych, czy prawa pracy?

Rola skarbnika może okazać się niebagatelna, ale jest mocno uzależniona od wielkości JST, czy jej struktury organizacyjnej, a także od cech charakteru osoby piastującej to stanowisko. W praktyce może się zdarzyć, że zostanie on sprowadzony do roli zwykłego księgowego i jego obowiązki ograniczą się do ewidencjonowania operacji gospodarczych. Niekiedy jednak zakres jego obowiązków może wykroczyć także poza określone w ustawie obowiązki².

Miasto. Pamięć i Przyszłość 3/2 (2018) ISSN 2543-621X

\section{Pojęcie skarbnika miasta}

Zgodnie z art. 91 ustawy z dnia z dnia 5 czerwca 1998 r. o samorządzie powiatowym³, „prawa powiatu przysługują miastom, które w dniu 31 grudnia 1998 r. liczyły więcej niż 100000 mieszkańców". Do grupy takich miast należał wówczas również Wrocław. Jednocześnie przyjęto, że Rada Ministrów mogła odstąpić od nadania tych praw, gdyby miało to ograniczyć wspólnotom samorządowym istniejącym w ramach dotychczasowego powiatu dostęp do usług publicznych, o charakterze powiatowym ${ }^{4}$. W przypadku Wrocławia z tej przesłanki nie skorzystano.

1. P. Walczak, Wstęp [w:] Vademecum skarbnika jednostki samorzqdu terytorialnego, red. P. Walczak, Warszawa 2018.

2. J. Glumińska-Pawlic, D. Kamińska, Pozycja prawna i faktyczna skarbnika gminy [w:] Księga Jubileuszowa ku czci Profesor Krystyny Sawickiej. Gromadzenie wydatkowanie środków publicznych. Zagadnienia finansowoprawne, red. W. Miemiec, Wrocław 2017, s. 171.

3. Ustawa z dnia 5 czerwca 1998 r. o samorządzie powiatowym (Dz. U. z 2018 r. poz. 995 z późn. zm.), zwana dalej w skrócie usp.

4. A. Wierzbica, Art. 91 [w:] Ustawa o samorzadzie powiatowym. Komentarz, red. B. Dolnicki, Kraków 2007. Przepis ten utracił moc w wyniku nowelizacji ustawą z dnia 11 kwietnia 2001 r. o zmianie ustaw: o samorządzie gminnym, o samorządzie powiatowym, o samorządzie województwa, o administracji rządowej w województwie oraz o zmianie niektórych innych ustaw (Dz.U. Nr 45, poz. 497 z późn. zm.). 
Jak zauważa Jarosław Maćkowiak, art. 92 ust. 2 usp stanowi klauzule generalną, która nakłada na miasta na prawach powiatu stosowanie zasad ustrojowych powiatu, a więc rozszerza zakres kompetencji miast na prawach powiatu. Dla jego pełnego zobrazowania wymaga zatem sięgnięcia nie tylko do ustawy powiatowej, ale także do innych ustaw materialnych5.

Ustawa w art. 92 stanowi, że funkcje organów powiatu w miastach na prawach powiatu sprawuje rada miasta i prezydent miasta, a ustrój i działanie organów miasta na prawach powiatu, w tym nazwę, skład, liczebność oraz ich powoływanie i odwoływanie, a także zasady sprawowania nadzoru określa ustawa z dnia z dnia 8 marca 1990 r. o samorządzie gminnym6. Powyższe rozważania wskazują, że do określenia pozycji skarbnika miasta na prawach powiatu, właściwym będzie stosowanie w pierwszej kolejności ustroju gminy, a w konsekwencji lokalnego prawodawstwa.

O ustroju miasta na prawach powiatu decyduje przede wszystkim jego statut. Określa on m.in. organizację wewnętrzną oraz tryb pracy organów rady. Jeśli liczba ludności przekracza 300 000, statut miasta na prawach powiatu podlega uzgodnieniu z Prezesem Rady Ministrów na wniosek ministra właściwego do spraw

5. B. Dolnicki, Samorząd terytorialny, Warszawa 2016, s. 172.

6. Ustawa z dnia 8 marca 1990 r. o samorządzie gminnym (Dz. U. z 2018 r. poz. 994 z późn. zm.), zwana dalej w skrócie usg.

7. B. Dolnicki, dz. cyt.., s. 175.

8. Obecnie ujednolicony za sprawą Obwieszczenia Rady Miejskiej Wrocławia z dnia 14 września 2017 r. w sprawie ogłoszenia jednolitego tekstu uchwały nr XXVI/276/96 Rady Miejskiej Wrocławia z dnia 17 maja 1996 r. w sprawie przyjęcia Statutu Wrocławia w brzmieniu uzgodnionym z Prezesem Rady Ministrów (Dz. Urz. Woj. Dolnośl. z 2018 r., poz. 3965).

9. Ustawa z dnia z dnia 27 sierpnia 2009 r. o finansach publicznych (Dz. U. z 2017 r. poz. 2077 z późn. zm.), zwana dalej w skrócie ufp. administracji7. W przypadku Wrocławia jest to uchwała nr XXVI/276/96 Rady Miejskiej Wrocławia z dnia 17 maja 1996 r., do której załącznikiem jest Statut Wrocławiå.

Pojęcie Skarbnika Miasta pojawia się w rzeczonym Statucie po raz pierwszy w $\S$ 7, który stanowi o zakresie wyłącznej właściwości rady miasta. Między innymi w punkcie 3 znalazło się określenie procedury powoływania Skarbnika, które następuje na wniosek Prezydenta iasta. W tym przepisie dookreślono jednocześnie, że Skarbnik jest także głównym księgowym budżetu, co jest odpowiednim zastosowaniem regulacji zawartej w art. 18 ust. 1 pkt 3 usg, określającej skarbnika jako głównego księgowego budżetu.

\section{Kompetencje skarbnika Wrocławia}

Jak wspomniano, aby określić prawa i obowiązki skarbnika miasta, należy sięgnąć najpierw do przepisów ustawowych, a następnie w celu ich dookreślenia - do przepisów lokalnych.

Przepisy ustawowe, określające obowiązki skarbnika, odnajdziemy w art. 54 ustawy z dnia z dnia 27 sierpnia 2009 r. o finansach publicznych 9 . W ust. 8 zawarto uregulowanie stanowiące, że przepisy dotyczące głównego księgowego, które znajdują się przede wszystkim w art. 54 ufp, stosuje się odpowiednio do skarbnika (głównego księgowego budżetu jednostki samorządu terytorialnego). Zgodnie z tym artykułem kierownik jednostki powierza skarbnikowi obowiązki i odpowiedzialność w zakresie:

- prowadzenia rachunkowości jednostki;

Miasto. Pamięć i Przyszłość 3/2 (2018) ISSN 2543-621X 
- wykonywania dyspozycji środkami pieniężnymi;

dokonywania wstępnej kontroli zgodności operacji gospodarczych i finansowych z planem finansowym oraz kompletności i rzetelności dokumentów dotyczących operacji gospodarczych i finansowych.

W § 14 Regulaminu Organizacyjnego Urzędu Miejskiego Wrocławia10 został zawarty katalog zadań Skarbnika. Jego podstawowycelto wykonywanie zadań w zakresie gospodarki finansowej Wrocławia. Szczególnie istotny jest tu § 14 ust. 2, zawierający przykładowy katalog zadań Skarbnika Wrocławia. Do zadań tych należą:

1) opracowywanie projektów budżetu miasta;

2) prowadzenie księgowości budżetowej i gospodarki finansowej zgodnie z obowiązującymi przepisami;

3) opracowywanie sprawozdań finansowych z wykonania budżetu miasta;

4) kontrasygnowanie oświadczeń woli mogących spowodować powstanie zobowiązań pieniężnych;

5) opiniowanie projektów uchwał rady miejskiej i zarządzeń prezydenta w sprawach dotyczących zobowiązań finansowych;

6) nadzór nad gospodarowaniem środkami budżetowymi miasta, a w szczególności nad przestrzeganiem dyscypliny finansów publicznych;

7) wydawanie decyzji administracyjnych w indywidualnych sprawach z zakresu administracji publicznej w zakresie upoważnień udzielonych przez prezydenta;

Miasto. Pamięći Przyszłość 3/2 (2018) ISSN 2543-621X 111
8) wykonywanie innych zadań powierzonych przez prezydenta.

Rola Skarbnika Wrocławia ujawnia się m.in. w trybie podejmowania uchwały budżetowej. Uchwała w sprawie trybu prac nad projektem uchwały budżetowej"1 przekazuje główną rolę przy jej procedowaniu Prezydentowi Wrocławia. Skarbnik Miasta pojawia się w niej zaledwie dwukrotnie. W § 6 ust. 5 tej uchwały Skarbnik Wrocławia może z upoważnienia Prezydenta Wrocławia przedstawić na wniosek klubów, komisji i radnych dodatkowe wyjaśnienia dotyczące projektu uchwały budżetowej. Na mocy wspomnianej uchwały skarbnik uczestniczy jednocześnie w pracach Komisji Budżetu i Finansów, która po pierwszym czytaniu projektu uchwały budżetowej ma za zadanie dokonać jego ostatecznego zaopiniowania.

W tym ujęciu o wiele istotniejsza staje się funkcja kierownicza Skarbnika. Regulamin Organizacyjny określa, że Skarbnika Miasta zalicza się - obok Sekretarza Miasta Wrocławia i wiceprezydentów - do kierownictwa urzędu. Jak wynika z \$14 ust. 5 Regulaminu Organizacyjnego, Skarbnik kieruje Departamentem Finansów Publicznych. Załącznik nr 1 do zarządzenia nr 9418/18 Prezydenta Wrocławia z dnia 28 marca 2018 r. ukazuje w graficzny sposób schemat organizacyjny urzędu. Wynika z niego, że w ramach Departamentu Finansów Publicznych

10. Zarządzenie nr 9418/18 Prezydenta Wrocławia z dnia 28 marca 2018 r. w sprawie Regulaminu Organizacyjnego Urzędu Miejskiego Wrocławia, http://bip.um.wroc.pl/artykul/147/32359/regulamin-organizacyjny-umw [dostęp: 28.05.2018], dalej jako Regulamin Organizacyjny.

11. Uchwała nr XVII/320/15 Rady Miejskiej Wrocławia z dnia 15 października 2015 r. w sprawie trybu prac nad projektem uchwały budżetowej, http://uchwaly.um.wroc.pl/uchwaly_tytul. aspx [dostęp: 28.05.2018]. 
skarbnikowi miasta Wrocławia podlegają:

1) Wydział Podatków i Opłat;

2) Wydział Zarządzania Należnościami;

3) Wydział Finansowy;

4) Wydział Księgowości;

5) Wydział Należności Środowiskowych.

Skarbnik miasta wchodzi także w skład Kolegium Prezydenta, będącego organem opiniodawczo-doradczym ( $\$ 33$ regulaminu organizacyjnego).

Na wniosek skarbnika dyrektorzy wydziałów i biur, pracownicy komórek organizacyjnych oraz inne osoby mogą otrzymywać upoważnienia do składania oświadczeń woli w zakresie praw i obowiązków miasta, w tym praw i obowiązków majątkowych oraz pełnomocnictwa (§ 37 Regulaminu Organizacyjnego).

Skarbnik opracowuje instrukcję, w której określa zasady obiegu dokumentów finansowo-księgowych w ramach urzędu. Prezydent wprowadza ją w drodze odrębnego zarządzenia (§ 49 Regulaminu Organizacyjnego).

Przy ewentualnym wykonywaniu innych kompetencji i zadań powierzonych przez Prezydenta, Skarbnik działa w granicach określonych imiennymi pełnomocnictwami i upoważnieniami.

\section{Kontrasygnata}

Kontrasygnata skarbnika stanowi kategorię prawa publicznego, choć także wywołuje ona skutki na gruncie cywilnoprawnym².

12. K. Lange, Wybrane aspekty cywilnoprawne kontrasygnaty skarbnika jednostki samorzadu terytorialnego, "Finanse Komunalne” 2009, nr 9, s. 10.

13. B. Dolnicki, Pozycja prawna sekretarza i skarbnika w jednostkach samorzqdu terytorialnego [w:] Problemy doktrynalne i systemowe prawa publicznego, red. S. Pikulski, W. Pływaczewski, J. Dobkowski, Olsztyn 2002, s. 110.
Jak stanowi § 43 Regulaminu Organizacyjnego, projekt aktu prawnego, którego skutkiem może być powstanie zobowiązań pieniężnych, podlega uzgodnieniu ze skarbnikiem, zaś § 10 tegoż Regulaminu wskazuje, że przy wszystkich czynnościach prawnych, mogących spowodować powstanie zobowiązań finansowych miasta, bezwzględnie wymagana jest kontrasygnata Skarbnika lub osoby przez niego upoważnionej. Z kontrasygnaty wynika przede wszystkim to, że:

1) skarbnik sprawdził, że operacja została uznana przez właściwych rzeczowo pracowników za prawidłową merytorycznie,

2) skarbnik nie zgłosił zastrzeżeń co do legalności operacji i rzetelności dokumentu,

3) JST dysponuje środkami finansowymi na pokrycie zobowiązań wynikających z operacji gospodarczej oraz jest ona uwzględniona w planie budżetu lub planie finansowym,

4) skarbnik skontrolował formalno-rachunkową prawidłowość dokumentu dotyczącego operacji13.

Przyjmuje się, że czynność zaciągającą zobowiązania pieniężne a pozbawioną kontrasygnaty skarbnika należy uznać za czynność obarczoną specyficzną sankcją bezskuteczności, która jest jedynie zbliżona do bezskuteczności zawieszonej. Podobnie jak ona, nie wyłącza stanu związania stron złożonymi oświadczeniami woli, jednak odmowa kontrasygnaty przez skarbnika nie powoduje bezwzględnej nieważności tej czynności prawnej14. Wynika to przede wszystkim z art. 46 ust. 4 usg,stanowiącego, że skarbnik miasta

Miasto. Pamięć i Przyszłość 3/2 (2018) ISSN 2543-621X 
(gminy), który odmówił kontrasygnaty, dokona jej jednak na pisemne polecenie zwierzchnika, powiadamiając o tym radę gminy oraz regionalną izbę obrachunkową.

Sąd Najwyższy w wyroku z dnia 6 listopada 2014 r.15 stwierdził, że dopuszczalne jest udzielenie kontrasygnaty także w sposób konkludentny. Uznał on, że przystąpienie do realizacji umowy może być uznane za potwierdzenie jej zawarcia i jednocześnie za złożenie w sposób dorozumiany kontrasygnaty przez skarbnika. Odmowa udzielenia kontrasygnaty, jak podkreśla się w literaturze, wymaga formy pisemnej i powinna być odpowiednio umotywowana ${ }^{16}$.

\section{Powołanie}

Zgodnie z \& 7 pkt 3 Statutu Wrocławia, do wyłącznej właściwości Rady Miejskiej Wrocławia należy powoływanie i odwoływanie - na wniosek Prezydenta Miasta - Skarbnika Miasta. Analogicznie § 55 wśród egzemplifikacji zadań Prezydenta Miasta wymienia zgłaszanie Radzie wniosków w sprawie kandydatur na stanowiska Skarbnika.

Prawidłowe powołanie skarbnika następuje więc dopiero po zaistnieniu dwóch przesłanek: wystąpienia przez prezydenta miasta z wnioskiem do rady miasta o powołanie skarbnika miasta, a następnie powołanie przez radę osoby wskazanej we wniosku przez. Pominięcie jednego z tych etapów uniemożliwia skuteczne powołanie skarbnika miastaำ. Zdaniem Stefana Płażka rada gminy nie może odmówić podjęcia uchwały tylko z powodu odmiennego postrzegania

Miasto. Pamięć i Przyszłość 3/2 (2018) ISSN 2543-621X przedstawionego kandydata, podobnie jak nie może go odwołać bez wniosku prezydenta, nawet gdyby spostrzegła, że skarbnik nie posiada wymaganych na tym stanowisku kwalifikacji18.

Jak wynika z art. 4 pkt 2 ustawy z dnia 21 listopada 2008 r. o pracownikach samorządowych"19, skarbnik miasta (gminy) jest zatrudniany na podstawie powołania. Pracodawcą samorządowym osoby zatrudnionej na stanowisku skarbnika miasta jest urząd miejski, a funkcję zwierzchnika służbowego sprawuje w odniesieniu do skarbnika wójt lub prezydent miasta20. Jak stanowi § 70 Statutu Wrocławia, Prezydent Miasta wykonuje obowiązki pracodawcy wobec osób powołanych na stanowisko Skarbnika Miasta.

Szukając wymagań, które spełnić musi osoba mająca pełnić funkcję skarbnika, należy sięgnąć do ust. 2 wspomnianego już art. 54 upf. Zgodnie z jego treścią, skarbnikiem miasta może być osoba, która:

1) ma obywatelstwo państwa członkowskiego Unii Europejskiej, Konfederacji Szwajcarskiej lub państwa członkowskiego Europejskiego Porozumienia o Wolnym Handlu (EFTA) - strony umowy o Europejskim Obszarze Gospodarczym, chyba że odrębne ustawy

14. Więcej o charakterze prawnym kontrasygnaty: M. Dumkiewicz, Skutki braku kontrasygnaty skarbnika gminy na tle sankcji wadliwych czynności prawnych, "Przegląd Prawa Handlowego" 2013, nr 9 (253).

15. Wyrok Sądu Najwyższego z dnia 6 listopada 2014 r., II CSK 28/14, OSNC - ZD 2016, nr 1, poz. 9.

16. J. Glumińska-Pawlic, D. Kamińska, dz. cyt., s. 173.

17. A. Wierzbica, Pozycja prawna skarbnika jednostki samorząu terytorialnego, „Finanse Komunalne”, 2008, nr 4, s. 8.

18. S. Płażek, O obecnym statusie pracowniczym skarbnika jednostki samorzadu terytorialnego, "Finanse Komunalne”, 2014, nr 5, s. 7.

19. Ustawa z dnia 21 listopada 2008 r. o pracownikach samorządowych (Dz. U. z 2018 r. poz. 1260).

20. A. Wierzbica, dz. cyt., s. 7. 
uzależniają zatrudnienie w jednostce sektora finansów publicznych od posiadania obywatelstwa polskiego;

2) ma pełną zdolność do czynności prawnych oraz korzysta z pełni praw publicznych;

3) nie była prawomocnie skazana za przestępstwo przeciwko mieniu, przeciwko obrotowi gospodarczemu, przeciwko działalności instytucji państwowych oraz samorządu terytorialnego, przeciwko wiarygodności dokumentów lub za przestępstwo skarbowe;

4) wyróżnia się znajomością języka polskiego w mowie i piśmie w zakresie koniecznym do wykonywania obowiązków głównego księgowego;

5) spełnia jeden z poniższych warunków:

a) ukończyła ekonomiczne jednolite studia magisterskie, ekonomiczne wyższe studia zawodowe, uzupełniające ekonomiczne studia magisterskie lub ekonomiczne studia podyplomowe i posiada co najmniej 3-letnią praktykę w księgowości,

b) ukończyła średnią, policealną lub pomaturalną szkołę ekonomiczną i posiada co najmniej 6-letnią praktykę w księgowości,

c) jest wpisana do rejestru biegłych rewidentów na podstawie odrębnych przepisów,

21. Ustawa z dnia 21 listopada 2008 r. o pracownikach samorządowych (Dz.U. 2018 poz. 1260) zwana dalej jako ups.

22. S. Płażek, dz. cyt., s. 8-9.

23. E. Ura, Skarbnik gminy, powiatu województwa [w:] Encyklopedia samorzadu terytorialnego, red. K. Miaskowska-Daszkiewicz, B. Szmulika, Warszawa 2010, s. 748.

24. A. Wierzbica, dz. cyt., s. 12. d) posiada certyfikat księgowy uprawniający do usługowego prowadzenia ksiąg rachunkowych albo świadectwo kwalifikacyjne uprawniające do usługowego prowadzenia ksiąg rachunkowych, wydane na podstawie odrębnych przepisów.

Na uwagę zasługuje fakt, że na gruncie ustawy o pracownikach samorządowych ${ }^{21}$ skarbnik nie został zakwalifikowany ani do grupy stanowisk urzędniczych, ani wyższych urzędniczych. Stan obecny jest taki, że skarbnika nie obowiązują żadne wymagania etyczne (nieposzlakowana opinia czy apolityczność), a arbitralną władzę dotyczącą jego powoływania i odwoływania sprawuje prezydent miasta ${ }^{22}$. Na gruncie ustawy do skarbnika odnoszą się jedynie przepisy dotyczące pracowników samorządowych zatrudnionych w drodze powołania. Nie zmieniają one jednak sytuacji skarbnika, stanowią bowiem uogólnienie wcześniej przedstawionych regulacji23.

\section{Ograniczenia w pełnieniu funkcji skarbnika}

Procedura odwołania osoby z pełnienia funkcji skarbnika miasta jest analogiczna do procedury jego powołania. Rada gminy, po uprzednim otrzymaniu wniosku prezydenta miasta, musi podjąć uchwałę, na mocy której skarbnik zostanie odwołany.

W przypadku naruszenia tzw. przepisów antykorupcyjnych, nie jest wymagany wniosek prezydenta miasta, a odwołanie jest obligatoryjne i następuje w drodze uchwały rady miasta ${ }^{24}$.

Miasto. Pamięć i Przyszłość 3/2 (2018) ISSN 2543-621X 
Przepisy antykorupcyjne wprowadzają dla osoby na stanowisku skarbnika wiele ograniczeń. Zgodnie z ustawą z dnia 21 sierpnia 1997 r. o ograniczeniu prowadzenia działalności gospodarczej przez osoby pełniące funkcje publiczne ${ }^{25}$, skarbnik nie może jednocześnie m.in. być członkiem zarządów, rad nadzorczych lub komisji rewizyjnych spółek prawa handlowego i spółdzielni, z wyjątkiem rad nadzorczych spółdzielni mieszkaniowych; być zatrudnionym lub wykonywać inne zajęcia w spółkach prawa handlowego, które mogłyby wywołać podejrzenie o ich stronniczość lub interesowność; być członkiem zarządów fundacji prowadzących działalność gospodarczą; posiadać w spółkach prawa handlowego więcej niż 10\% akcji lub udziały przedstawiające więcej niż 10\% kapitału zakładowego - w każdej z tych spółek; prowadzić działalności gospodarczej na własny rachunek lub wspólnie z innymi osobami.

Art. 24h usg nakłada na skarbnika obowiązek złożenia oświadczenia o swoim stanie majątkowym. Oświadczenie majątkowe dotyczy zarówno jego majątku odrębnego, jak i majątku objętego małżeńską wspólnotą majątkową. Skarbnik składa pierwsze oświadczenie majątkowe w terminie 30 dni od dnia powołania na stanowisko. Jednocześnie jest obowiązany dołączyć informację o sposobie i terminie zaprzestania prowadzenia działalności gospodarczej, jeżeli prowadził ją przed dniem powołania. Kolejne oświadczenia majątkowe są składane przez skarbnika co roku do dnia 30 kwietnia, według stanu na dzień 31 grudnia roku poprzedniego oraz w dniu odwołania ze

Miasto. Pamięć i Przyszłość 3/2 (2018) ISSN 2543-621X 115 stanowiska. Jeżeli skarbnik miasta nie złoży w terminie oświadczenia majątkowego, rada gminy odwołuje go w drodze uchwały, najpóźniej po upływie 30 dni od dnia, w którym upłynął termin złożenia oświadczenia. Odwołanie jest równoznaczne z rozwiązaniem umowy o pracę bez wypowiedzenia na podstawie art. 52 § 1 pkt 1 Kodeksu pracy ${ }^{26}$.

Skarbnik ma ustawowy obowiązek ujawniania informacji, których katalog znajduje się w art. 12 ust. 3 ustawy antykorupcyjnej, w utworzonym w tym celu Rejestrze Korzyści. Przy podawaniu informacji skarbnik winien zachować największą staranność i kierować się swoją najlepszą wiedzą. Wszelkie zmiany danych objętych rejestrem należy zgłaszać nie później niż w ciągu 30 dni od dnia ich zaistnienia ${ }^{27}$.

\section{Odpowiedzialność skarbnika}

W kwestii odpowiedzialności skarbnika miasta powinno się sięgnąć przede wszystkim do ustawy z dnia 17 grudnia 2004 r. o odpowiedzialności za naruszenie dyscypliny finansów publicznych ${ }^{28}$. Art. 18b uondfp określa, że w przypadku kontroli wstępnej dokonanie wydatku powodującego przekroczenie kwoty wydatków ustalonej w planie finansowym jednostki sektora finansów publicznych lub zaciągnięcie zobowiązania niemieszczącego się w planie finansowym jednostki sektora finansów

25. Ustawa z dnia 21 sierpnia 1997 r. o ograniczeniu prowadzenia działalności gospodarczej przez osoby pełniące funkcje publiczne (Dz. U. z 2017 r. poz. 1393.) zwana dalej ustawą antykorupcyjną.

26. Ustawa z dnia 26 czerwca 1974 r. Kodeks pracy (Dz. U. z 2018 r. poz. 917).

27. A. Wierzbica, dz. cyt., s. 17.

28. Ustawa z dnia 17 grudnia 2004 r. o odpowiedzialności za naruszenie dyscypliny finansów publicznych (Dz. U. z 2017 r. poz. 1311), zwana dalej w skrócie uondfp. 
publicznych stanowi naruszenie dyscypliny finansów publicznych. Ta regulacja nie dotyczy jednak nieprawidłowości związanych z zaciąganiem przez jednostki samorządu terytorialnego zobowiązań wieloletnich, dla których podstawą zaciągnięcia są upoważnienia zawarte w uchwale w sprawie wieloletniego planu finansowego, a nie plan wydatków budżetu (plan finansowy) ${ }^{29}$. W ramach kontroli wstępnej tych zobowiązań skarbnik miasta nie poniesie odpowiedzialności.

W przypadku uchybień w realizacji obowiązku wykonywania dyspozycji środkami pieniężnymi skarbnik jako główny księgowy ponosi odpowiedzialność pracowniczą na zasadach ogólnych. Może do tego dojść także odpowiedzialność karna. Nie będzie on jednak podlegał odpowiedzialności za naruszenie dyscypliny finansów publicznych, bo żaden przepis uondfp nie przewiduje karania uchybień w zakresie wykonywania dyspozycji środkami pieniężnymizo.

Podkreślić ponadto należy, że skarbnik ponosi odpowiedzialność jedynie w zakresie czynów związanych bezpośrednio z jego obowiązkami, a przekazanie mu obowiązków i odpowiedzialności nie znosi jednocześnie odpowiedzialności kierownika jednostki z tytułu nadzoru¹.

\section{Podsumowanie}

Jak można zauważyć, pełne scharakteryzowanie pozycji prawnej skarbnika miasta wymaga sięgnięcia do wielu aktów rangi ustawowej, a także do właściwych aktów prawa miejscowego i aktów prawa wewnętrznego. Skarbnik zajmuje szczególne miejsce wśród osób zatrudnionych w ramach administracji miasta na prawach powiatu oraz został wyposażony w szczególne uprawnienia, z którymi połączono wiele obowiązków i zakazów. Ze sprawowaniem kontroli wstępnej wiąże się także dodatkowa odpowiedzialność. Kluczową kwestią dla funkcjonowania finansów miasta, które wszak są związane praktycznie z wszelkimi rodzajami działań podejmowanych przez jednostkę samorządu terytorialnego, jest obsadzenie na tym stanowisku właściwej osoby.
29. P. Walczak, Art. 54 [w:] Ustawa o finansach publicznych. Komentarz dla jednostek samorządowych, red. P. Walczak, Warszawa 2017.

30. M. Bitner, Art. 54 [w:] Ustawa o finansach publicznych. Ustawa o odpowiedzialności za naruszenie dyscypliny finansów publicznych. Komentarz, red. W. Misiong, Warszawa 2017.

31. J. Glumińska-Pawlic, D. Kamińska, dz. cyt., 175.
Miasto. Pamięć i Przyszłość 3/2 (2018) ISSN 2543-621X 


\section{Literatura:}

- M. Bitner, Art. 54 [w:] Ustawa o finansach publicznych. Ustawa o odpowiedzialności za naruszenie dyscypliny finansów publicznych. Komentarz, red. W. Misiong, Warszawa 2017.

- B. Dolnicki, Pozycja prawna sekretarza i skarbnika w jednostkach samorzadu terytorialnego [w:] Problemy doktrynalne i systemowe prawa publicznego, red. S. Pikulski, W. Pływaczewski, J. Dobkowski, Olsztyn 2002.

- B. Dolnicki, Samorzad terytorialny, Warszawa 2016.

- M. Dumkiewicz, Skutki braku kontrasygnaty skarbnika gminy na tle sankcji wadliwych czynności prawnych, "Przegląd Prawa Handlowego” 2013, nr 9 (253).

- K. Lange, Wybrane aspekty cywilnoprawne kontrasygnaty skarbnika jednostki samorzadu terytorialnego, "Finanse Komunalne" 2009, nr 9.

- J. Glumińska-Pawlic, D. Kamińska, Pozycja prawna i faktyczna skarbnika gminy [w:] Księga Jubileuszowa ku czci Profesor Krystyny Sawickiej. Gromadzenie wydatkowanie środków publicznych. Zagadnienia finansowoprawne, red. W. Miemiec, Wrocław 2017.

- S. Płażek, O obecnym statusie pracowniczym skarbnika jednostki samorzqdu terytorialnego, „Finanse Komunalne" 2014, nr 5.

- E. Ura, Skarbnik gminy, powiatu województwa [w:] Encyklopedia samorzadu terytorialnego, red. K. Miaskowska-Daszkiewicz, B. Szmulika, Warszawa 2010.

- P. Walczak, Wstęp [w:] Vademecum skarbnika jednostki samorzadu terytorialnego, red. P. Walczak, Warszawa 2018.

- P. Walczak, Art. 54 [w:] Ustawa o finansach publicznych. Komentarz dla jednostek samorządowych, red. P. Walczak, Warszawa 2017.

- A. Wierzbica, Art. 91 [w:] Ustawa o samorzadzie powiatowym. Komentarz, red. B. Dolnicki, Warszaa 2007.

- A. Wierzbica, Pozycja prawna skarbnika jednostki samorząu terytorialnego, "Finanse Komunalne" 2008, nr 4. 